\title{
What makes EFL speakers' utterances more intelligible in the context of global intelligibility?
}

\author{
Moedjito*, Selamet Riadi Jaelani, and Maman Asrobi \\ Department of English Language Education, Faculty of Language, Art, and Humanities, Universitas Hamzanwadi, \\ Jl. Cut Nyak Dien No.85, Pancor, Selong, Kabupaten Lombok Timur, Nusa Tenggara Barat, Indonesia
}

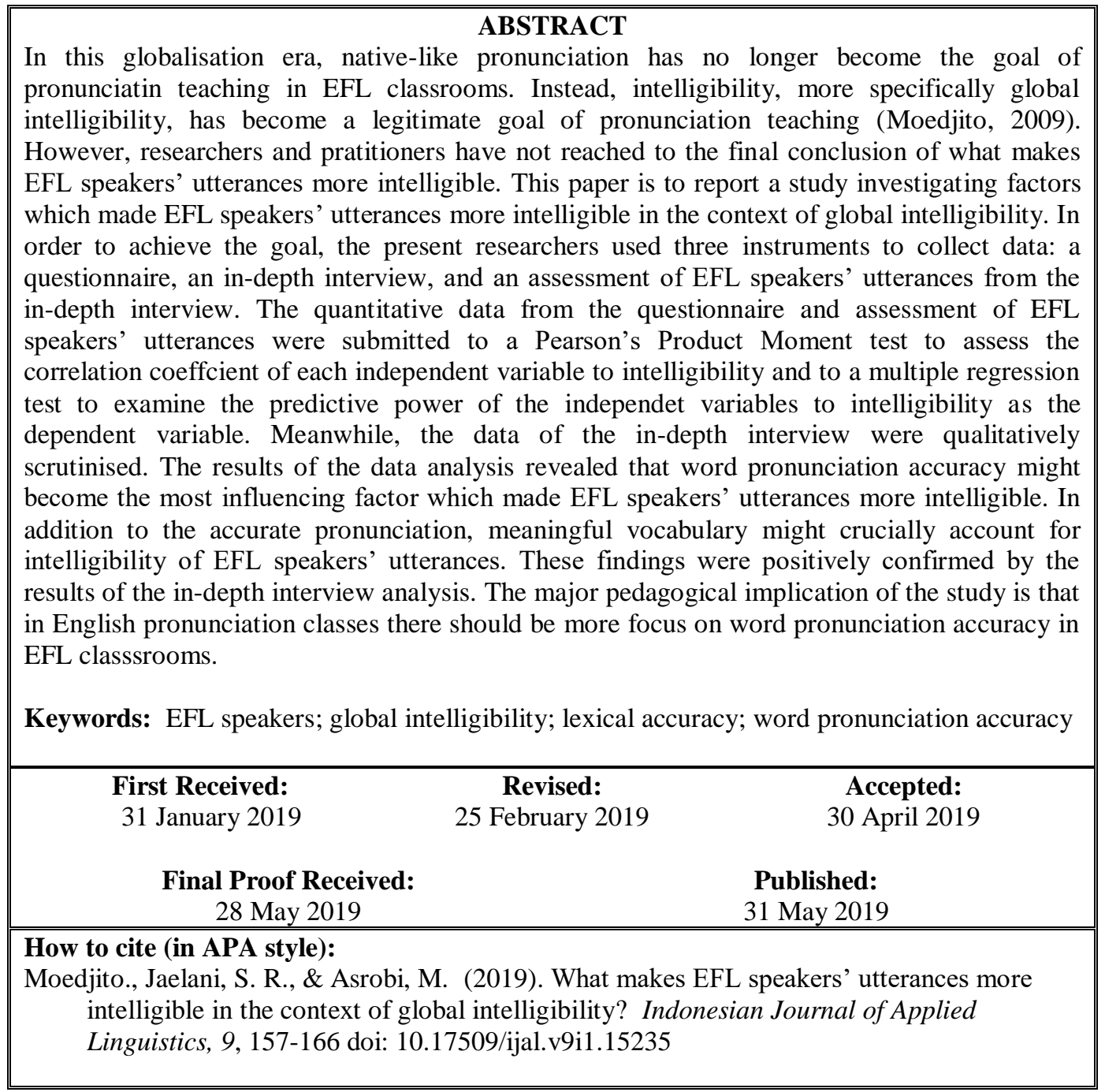

\section{INTRODUCTION}

In a historical perspective, it is noted that at one period of time pronunciation was elevated to the top priority of ESL/EFL teaching/learning. On other times, however, pronunciation was almost sidelined, even almost neglected as in the grammar-translation method. It is also understandable that the paradigm shift of pronunciation teaching is greatly influenced by the selected approach with its underlying theories of language and theories of language learning. A careful examination of the development of English language teaching has shown that nowadays the contemporary trend of English language teaching is not only affected by the underlying theories of language and theories of language learning, but also the status of English in relation to what is happening in the world, that is globalisation (Moedjito, 2009).

\footnotetext{
* Corresponding Moedjito

Email: mas.moedjito@gmail.com
} 
According to Graddol (1997), the globe of the world has been changing by the rapid growth of world economics, science, technogy, and cultures, which become increasingly interconnected and interdependent, politically, socially, and technologically. After nine years of his argumentation, Graddol (2006) in his English Next states that "the future of English has become more closely tied to the future of globalisation itself" (p. 13). This implies that the status of English as a global language is remarkably influenced by what is happening in the globe.

Considering the number of English speakers in the world, Lyons (2017) claims that there are about 1.5 billion persons or about $20 \%$ of the world's population, comprising around 360 million native speakers of English (NSs) and around 1.14 billions of non-native English speakers (NNSs), either as a second language or as a foreign language. Thus, English is still needed for the connection among people from different first language backgrounds. A huge of data supports this fact. For example, in terms of finance, technology, science, and trade, Australia, Canada, New Zealand, the United Kingdom, and the United States recognised as the Anglosphere-where English is spoken as the first language - already plays an important role (Campanella $\&$ Dassù, 2017). In terms of tourism, there were around 1.2 billion international travellers in 2017, comprising 134.8 million persons to North America, 323.1 million persons to Asia Pacific, 58.1 million persons to Middle East, and 670.6 million persons to Europe. This implies that there is a need more face-to-face international interaction and that there is a growing role of English as a global language (The Statistics Portal, 2018). As far as language on Internet is concerned, English still dominates computers and internet than other languages. Out of the estimated 1.5 billion persons in the world that speak English, 1.1 billion persons $(72.2 \%)$ use the internet. This number corresponds to $25.4 \%$ of all the users (Internet World Stats, 2018). Taking these small figures only into account, it is inarguably true that English is really a global language.

Based on Moedjito's (2009) historical review of pronunciation teaching from the period of teaching knowledge to the period of teaching communication, it may be summarised that in the period of teaching knowledge and the period of teaching skills, the goal of pronunciation teaching is to enable learners to have near-native or native-like pronunciation. However, this target is too ideal and might not be attainable (Abercrombie, 1956); therefore, native-like pronunciation of English is not legitimate as a goal of pronunciation teaching for ESL/EFL learners in the context of English as a global language. To be the goal of pronunciation teaching, native-like pronunciation has several deficiencies. First, it is difficult to address the concept of native English because there is no clear-cut definition of native English; which is native and which is non-native. Secondly, although the basic division of native and non-native dichotomy can be formulatedfor example McArthur's (1992) definition of native and non-native English speakers which was based on those born to the language and those who learnt it through education respectively-there are many native varieties of English such as the Received Pronunciation, the General American, Australian English, Canadian English, and other varieties. To be a model for speaking, it must really be confusing. Thirdly, in the context of globalisation English is not only a means of oral communication by NSs and NNSs, but also among NNSs who come from different cultural and linguistic backgrounds. This oral communication across cultures requires a certain type of English which can secure the successful interactions. For example, in a section on English in the globalised workplace, "English must service a range of corporate roles and identities and must be usable for both team-working and service interactions" (Graddol, 1997, p. 43). In addition to these reasons, ESL/EFL research on the critical period hypothesis $(\mathrm{CPH})$ contributes to the necessary shift of native-like pronunciation to intelligibility. A number of studies on the relationship between age of acquisition and second language development have revealed that 'perfect pronunciation' and/or 'near-native pronunciation', and/or mastery of pronunciation are virtually unattainable for the vast majority of ESL/EFL learners (Morley, 1991).

As an ESL/EFL teacher, the first question may be addressed in pronunciation teaching related to English as a global language is What kind model of English pronunciation should I teach to my students? In the earlier days, the answer may be simply the undifferentiated British English or American English. To be extended, beside General American and the British Received Pronunciation, it may be other possibilities such as those native varieties spoken in Australia, Canada, New Zealand, and South Africa. But now, as an impact of globalisation, it is more difficult to provide an appropriate answer because there are also foreign-language varieties such as Japanese English (Japlish), Singaporean English (Singlish), and many others. The appropriate candidate to answer the question may be English spoken by many people in the globe, either as a working language or as a daily life language. However, which model of pronunciation is still unclear. For this reason, it is necessary to address which type of English is appropriate as a model of pronunciation teaching in EFL classrooms.

According to von Schon (1987), there are four criteria for choosing a model for pronunciation teaching: (1) a model of English which is most admired in our own region, (2) a model of English which is most useful for our students, (3) a model of English which is most consonant with the attitude of our school administration, and (4) the availability of teaching materials such as textbooks, tapes, and others. As a concluding remark, von Schon strongly recommended that some standard from near top of the cline should be considered; for example, Japanese English in Japan or Indonesian English in Indonesia. 
Taking into account the criteria proposed by von Schon and the globalisation which provides the English language users opportunities to communicate orally in English with other English users, pronunciation teaching should aim to enable learners to achieve intelligibility, which is more realistic and attainable. However, which intelligibility should EFL speakers aim for?

The discussion of intelligibility cannot be separated from the models of oral communication among English users (Moedjito, 2009). As illustrated in Figure 1, in real life, not only does oral communication happen between NSs and NNSs, whether between English as a native language (ENL) speakers and EFL speakers or between ENL speakers and ESL speakers (Celce-Murcia, Brinton, \& Goodwin, 1996; Cole, 2002; Cruttenden, 2001; Jenkins, 2000; Morley, 1991; Munro, 2011; Zielinski, 2006), or between EFL speakers and
ESL speakers (Jenkins, 2000; Walker, 2001), but also among ENL speakers, EFL speakers, and ESL speakers (Moedjito, 2009). Each type of oral interaction needs a certain type of intelligibility on the part of speakers. When NNSs (EFL speakers and ESL speakers) communicate to NSs, they need a comfortable inteligibility (CI). Meanwhile, when NNSs (ESL speakers and EFL speakers) communicate to each other, they need mutual intelligibility (MI). However, in real life, not only may oral communication happen between NSs and NNSs, but also it does occur among ENL speakers, EFL speakers, and ESL speakers. In this situation, they need another type of intelligibility, that is global intelligibility (GI) as the goal of pronunciation teaching in EFL classrooms. Global intelligibility is defined as the property that NNSs need to possess when they communicate to NSs and to other NNS.

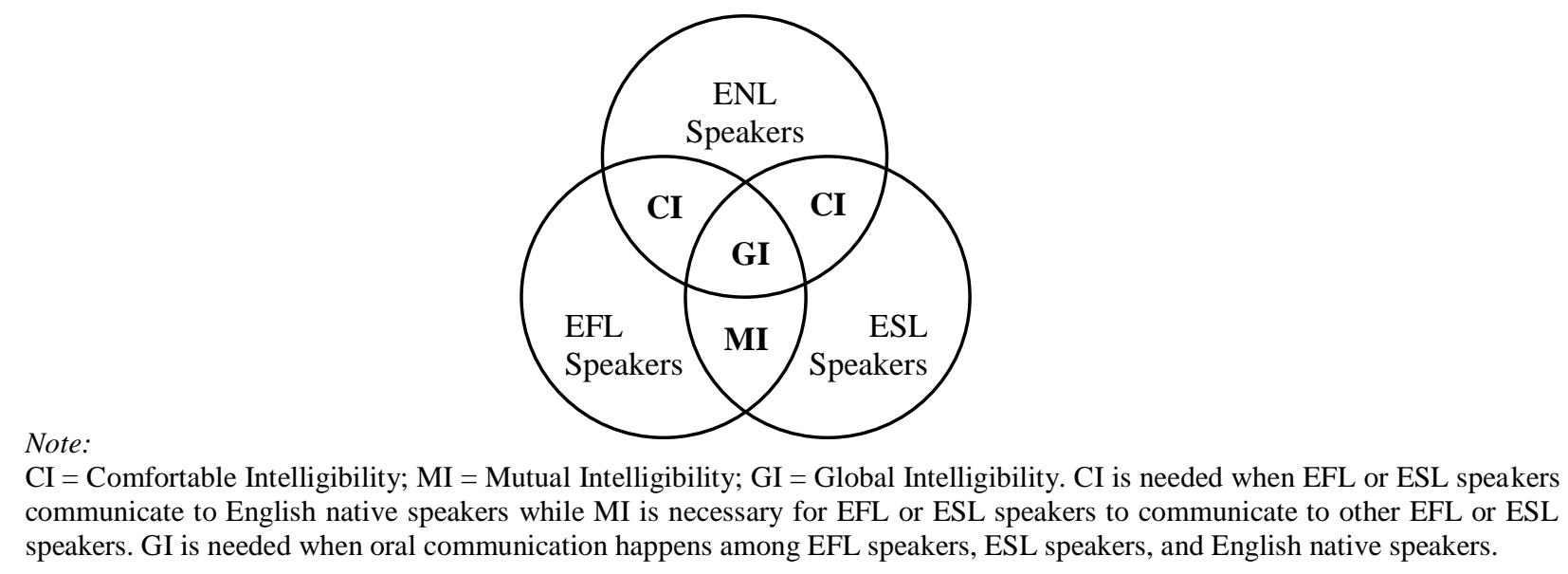

Figure 1. Model oral communication among English users

Assuming that global intelligibility is a legitimate goal of pronunciation teaching for EFL learners, the next questions is What factors may influence EFL speakers' global intelligibility? In broader sense, Kurum (2016) argues that speaking is more than to form grammatically correct sentences; it rather covers broad areas of mechanics, functions, pragmatics and social interaction. More specifically, a study concentrating on various aspects that can have a negative impact on the intelligibility and communicativeness of spoken utterances has disclosed that pronunciation, syntactic and lexical variations and deficiencies are analyzed in terms of the extent in which they can cause unintelligibility (Karoń, 2012). A recent study examining the relationship between variability in speaking rate, pausing and utterance length, and intelligibility and fluency ratings of non-native speech suggests that rating variability correlates with intelligibility of non-native speech, and rating variability does not correlate as strongly with fluency (Baese-Berk, 2017). Another study conducted by Becker and Kluge (2014) found that consonants and consonant clusters appeared to be fundamental for intelligibility. They also discovered that the production of individual vowel/consonant sounds was pointed out by the Brazilian listeners as the main factor of unintelligibility for Germans, Chinese and Japanese; meanwhile, it was the speech rate for Americans. To be more specific, Moedjito's (2009) study on factors influencing the intelligibility of EFL speakers' utterances revealed that there are four factors influencing EFL speakers' global intelligibility: sound accuracy, word stress, nuclear stress and adjustments in connected speech. A follow-up research of this finding discovered that accurate pronunciation (sound accuracy) was the most influencing factor for both comfortable and mutual intelligibility (Moedjito, 2018).

Regarding the importance of pronunciation as a key element of oral communication (Celce-Mucia et al., 1996; Gilakjani \& Ahmadi, 2011), especially in the context of global intelligibility, the current researchers were interested in investigating the factors influencing global intelligibility for non-native speakers of English. More specifically, the present study examined what factors made EFL speakers' utterances more intelligible in the context of global intelligibility. Thus, the main difference between the present study and the previous one is on the participants of the study. In the previous 
study, Moedjito (2009; 2018) involved ENL speakers, ESL speakers, and EFL speakers. Meanwhile, in the present study the researchers focused on the EFL speakers only.

\section{METHOD}

\section{Participants}

Sixty European EFL speakers (13 males and 47 female) from different first language backgrounds voluntarily participated in the current study. They were selected using an opportunistic sampling, meaning that we took the sample from people who were available at the time the study was carried out and fitted the criteria we were looking for (i.e., they were non-native speakers of English; they were voluntarily willing to participate in the present study; and they had enough speaking ability in English to maintain the flow of conversation). Prior to selecting the sample, the researchers did an intensive observation in Gili Terawangan, the regency of Lombok Utara, the province of Nusa Tenggara Barat, Indonesia as the site of the current study.

As displayed in Table 1, at the first stage, we selected 60 participants for the questionnaire and the indepth interview. Then, we reduced to 30 participants for the assessment of their real life utterances. These 30 participants were selected on the basis of the proportion of gender and their understanding of the linguistic terms related to the priorities of pronunciation, such as word pronunciation accuracy, word stress, nuclear stress, and adjustmens in connected speech.

Table 1. The participants' general information

\begin{tabular}{|c|c|c|c|c|c|c|c|}
\hline \multirow{2}{*}{ Country } & \multirow{2}{*}{ First Language (L1) } & \multicolumn{3}{|c|}{ Sample for Questionnaire } & \multicolumn{3}{|c|}{ Sample for In-Depth Interview } \\
\hline & & Female & Male & Subtotal & Female & Male & Subtotal \\
\hline Czech Republic & Czech & 4 & 1 & 5 & 2 & 1 & 3 \\
\hline Finland & Finish & 6 & 2 & 8 & 3 & 1 & 4 \\
\hline France & French & 8 & 3 & 11 & 3 & 2 & 5 \\
\hline Germany & German & 6 & 2 & 8 & 2 & 1 & 3 \\
\hline Italy & Italian & 6 & 2 & 8 & 3 & 1 & 4 \\
\hline Luxembourg & Luxembourgish & 3 & 1 & 4 & 2 & 1 & 3 \\
\hline Slovakia & Slovak & 2 & 0 & 2 & 1 & 0 & 1 \\
\hline Spain & Spanish & 5 & 0 & 5 & 2 & 0 & 2 \\
\hline Sweden & Swedish & 7 & 2 & 9 & 3 & 2 & 5 \\
\hline & Total & 47 & 13 & 60 & 21 & 9 & 30 \\
\hline
\end{tabular}

\section{Instruments}

To achieve the purpose of the study, three instruments were used: a questionnaire, an in-depth interview, and an assessment of EFL speakers' utterances. Before collecting data, we prepared a set of questionnaire, an interview protocol, and an assessment sheet. First, we constructed a questionnaire related to (1) the participants' personal information, (2) their experience in learning English, (3) their experience in learning English pronunciation, and (4) their opinion about English pronunciation. Although we had an extensive data colected from the questionnaire, our main focus was on the factors influencing EFL speakers' global intelligibility. Then, we developed an interview protocol adapted from Moedjito's (2016a) interview guide. As the purpose of the in-depth interview was to confirm the items in the questionnaire, basically the content of this protocol was similar to the questionnaire. Finally, we developed an assessment sheet to provide the empirical data of factors influencing EFL speakers' global intelligibility. In designing the assessment sheet, we first listed nine tentative factors contributing to global intelligibility through the analysis of preceding literature on this topic (e.g., Celce-Murcia et al., 1996; Jenkins, 2000; Moedjito, 2009; Morley, 1991). The assessment has ten components for evaluation: overall intelligibility and its nine contributing factors, covering (1) grammatical accuracy, (2) lexical accuracy, (3) word pronunciation accuracy), (4) word stress, (5) nuclear stress, (6) adjustments in connected speech, (7) intonation, (8) rhythm, (9) fluency, and (10) intelligibility. These ten components were arranged into an assessment sheet in which we used a five-point Likert scale (e.g., for example in terms of intelligibility, number 1 refers to the least intelligible utterance while number 5 refers to the most intelligible utterance). The details of the assessment sheet can be seen in the Appendix. In addition to the instruments, the present researchers prepared a list of technical terms related to priorities in pronunciation teaching and their short explanation.

\section{Data collection}

First, the prepared questionnaire was distributed to the participants. Because there were some linguistic terms which the participants might not understand, particularly related to the priorities in pronunciaion teaching, a prepared list of the technical terms was given to the participants. If they had not understood yet, our data collectors would explain the terms. The participants started to complete the questionnaire when they had really understood the terms.

After completing the questionnaire, all the participants were individually interviewed within 7-15 minutes, depending on the participants' responses to the questions, perticularly related to the factors influencing EFL speakers' global intelligibility as the main focus of the current study. The interview process was digitally video-recorded and controlled by using the prepared interview protocol. As described in the section 
Participants, although all the participants were individually interviewed, only 30 participants (9 males and 21 females) were taken as the sample for further analyses.

As the last step in data colection, the recorded EFL speakers' utterances collected during the in-depth interviews were then presented to two raters for evaluation through the prepared assessment sheet (see the Appendix). In order to evaluate, the raters were given two times to listen to the recorded EFL speakers' utterances.

\section{Data analysis}

The data collection resulted in three types of data: (1) the quantitative data collected from the questionnaire, (2) the qualitative data of the EFL speakers' real life utterances collected from the in-depth interview, and (3) the quantitative data as the result of the assessment of the EFL speakers' real life utterances from the in-depth interview by using the assessment sheet as shown in the Appendix. As there were two raters who evaluated the real life data, an interrater reliability analysis was performed to determine consistency among the raters using the Kappa statistics (McHugh, 2012). After calculating the Kappa statics, we found that the interrater reliability was significantly good, $\kappa=.81$ at $p$ $<.01$, meaning there was no significant difference in the raw scores of the two raters. Then, the average of the scores of the two raters was first calculated. Next, the data collected from the questionnaire and assessment sheet were tabulated and quantitatively analysed to get the descriptive statistics, correlation coefficients, and regression coefficients. The Pearson's correlation coefficients were calculated for nine contributing factors of intelligibility in order to find out which factors were eligible for multiple regression analyses which would in turn show the relationship between intelligibility and its contributing factors. As the criteria for the further analyses, the contributing factors should have at least a modest correlation to intelligibility or $r \geq .40$ (Moedjito, 2016a). All the statistical analyses were performed using IBM SPSS Statistics for Windows 22. In addition to the quantitative analyses, the data collected from in-depth interview were qualitatively scrutinised as confirmatory data.

\section{FINDINGS AND DISCUSSION \\ Descriptive statistics}

Table 2 displays the mean scores $(M)$, standard deviations $(S D)$, the Pearson's correlation coefficients $(r)$ of the factors determining intelligibility collected from both of the questionnaire and the assessment of the real life utterances, and the mean difference between the questionnaire and assessment. From the questionnaire, the results of data analysis discovered that there were five factors which had a high correlation to intelligibility (i.e., lexical accuracy, word pronunciation accuracy, word stress, nuclear stress, and rhythm) and one factor which had a modest correlation (i.e., intonation). Meanwhile, the results of data analysis of the assessment of the real life utterances revealed that there were two factors which had a high correlation to intelligibility (i.e., lexical accuracy and word pronunciation accuracy) and four factors which had a modest correlation (i.e., grammatical accuracy, word stress, nuclear stress, and adjustments in connected speech).

The result of the paired-sample t-test disclosed that there was a significant difference in the mean scores between data collected from the questionnaire and those collected from the assessment of the real life utterances, $t_{(\mathrm{df}=9)}=14.47$ at $p<.01$. A closer examination to the correlation coefficients revealed that there were four potential contributing factors to EFL speakers' global intellegibility, namely lexical accuracy, word pronunciation accuracy, word stress, and nuclear stress. This implies that the participants' perception of the contributing factors to intelligibility (the data collected from questionnaire) was partly different from the data of the assessment which represented the real life data of EFL speakers' utterances. Although there was a significant discrepancy between these two sets of data, for further analyses we focused on the data collected from the rater's assessment of the EFL speakers' utterances as they were the real life data.

Table 2. Summary of descriptive statistics, Pearson's coefficients, and mean differnce.

\begin{tabular}{lccccccc}
\hline \multirow{2}{*}{ Investigated Variables } & \multicolumn{3}{c}{ Questionnaire } & \multicolumn{3}{c}{ Rating } & \multicolumn{1}{c}{$\begin{array}{l}\text { Mean } \\
\text { Difference }\end{array}$} \\
\cline { 2 - 8 } & $\mathbf{M}$ & SD & $\mathbf{r}$ & $\mathbf{M}$ & SD & r & 0.97 \\
\hline Overall Intelligibility (I) & 3.16 & .85 & & 4.13 & .78 & \\
\hline Intelligibility Factors: & & & & & & & \\
$\quad$ Grammatical accuracy (GA) & 3.00 & .91 & .32 & 3.97 & .67 & $.47^{* *}$ & 0.97 \\
$\quad$ Lexical accuracy (LA) & 3.48 & .92 & $.68^{* *}$ & 4.17 & .75 & $.85^{* *}$ & 0.69 \\
Word pronunciation accuracy (WPA) & 3.08 & .81 & $.76^{* *}$ & 4.10 & .80 & $.92^{* *}$ & 1.02 \\
Word stress (WS) & 3.20 & .65 & $.62^{* *}$ & 3.87 & .73 & $.58^{* *}$ & 0.67 \\
Nuclear stress (SS) & 3.04 & .79 & $.67^{* *}$ & 3.90 & .76 & $.49^{* *}$ & 0.86 \\
Adjustments in connected speech (ACS) & 2.60 & .65 & .35 & 3.97 & .62 & $.43^{*}$ & 1.37 \\
Intonation (In) & 2.96 & .94 & $.59^{* *}$ & 4.00 & .79 & .06 & 1.04 \\
Rhythm (R) & 2.64 & .86 & $.71^{* *}$ & 3.40 & .77 & .09 & 0.76 \\
Fluency (F) & 3.12 & .78 & .22 & 4.10 & .66 & .03 & 0.98 \\
\hline
\end{tabular}

Note. Maximum score $=5.00$.

$$
* p<.05 ; * * p<.01
$$




\section{Influencing factors for intelligibility}

Although these correlation coefficients show the relationship of each factor to intelligibility, they cannot tell us much about the predictive power of the independent variables to the dependent variable (intelligibility). In order to show the relationship between intelligibility and its contributing factors, the data of the eligible variables (i.e., those which have at least a modest correlation, $r \geq .40$ ) from the assessment of the real life utterances, as the focus of the presnt study, were submitted to a multiple regression analysis with enter model. Thus, we just calculated the determinant coeficients for grammatical accuracy, lexical accuracy, word pronunciation accuracy, word stress, nuclear stress, and adjustments in connected speech.

After calculating the regression coefficents for the eligible variables, as displayed in Table 3, the results of data analysis revealed that there were only two variables, namely lexical accuracy and word pronunciation accuracy, which had significant contributions to intelligibility, $R^{2}=.73, p<.01$ and $R^{2}=$ $.84, p<.01$ respectively. This means that about $73 \%$ of the variation in intelligibility might be individually determined by lexical accuracy while $84 \%$ of the variation in intelligibility might be individually determined by word pronunciation accuracy.

A closer examination to the results, we found that both of lexical accuracy and word pronunciation accuracy had a significant contribution to global intelligibility, $R^{2}=.88, p<.01$. This indicates that word pronunciation accuracy and lexical accuracy can account directly for $88 \%$ of the variation in intelligibility and $12 \%$ of the variation in intelligibility might be explained by factors other than those investigated contributing factors.

Table 3. Summary of multiple regression analyses of potential contributing factors for intelligibility.

\begin{tabular}{llll}
\hline \multicolumn{1}{c}{ Potential Contributing Factors } & $\boldsymbol{B}$ & $\begin{array}{l}\boldsymbol{S E} \\
\boldsymbol{B}\end{array}$ & $\boldsymbol{\beta}$ \\
\hline (Constant) & .47 & .42 & \\
Grammatical accuracy (GA) & .01 & .11 & .09 \\
Lexical accuracy (LA) & .26 & .13 & $.25^{* *}$ \\
Word pronunciation accuracy & .65 & .11 & $.67^{* *}$ \\
(WPA) & & & \\
Word stress (WS) & .02 & .09 & .02 \\
Nuclear stress (SS) & - & .11 & -.06 \\
$\begin{array}{l}\text { Adjustments in connected speech } \\
\text { (ACS) }\end{array}$ & .16 & .09 & .13 \\
\hline
\end{tabular}
Note:

a. Dependent Variable: Intelligibility

b. Predictors: (Constant), Lexical Accuracy, $R^{2}=.73, p$ $<.01$

c. Predictors: (Constant), Word Pronunciation Accuracy, $R^{2}=.84, p<.01$

d. Predictors: (Constant), Word Pronunciation Accuracy and Lexical Accuracy, $R^{2}=.88, p<.01$

A closer examination to the results, we found that both of lexical accuracy and word pronunciation accuracy had a significant contribution to global intelligibility, $R^{2}=.88, p<.01$. This indicates that word pronunciation accuracy and lexical accuracy can account directly for $88 \%$ of the variation in intelligibility and $12 \%$ of the variation in intelligibility might be explained by factors other than those investigated contributing factors.

Comparing the quantitative data of the questionnaire and assessment of the EFL speakers' utterances with the qualitative data of the in-depth interview, we found that the quantitative data were positively confirmed by the qualitative data. All the EFL participants shared the same opinion that word pronunciation accuracy might be the most crucial for them to make their utterances more intelligible as seen in Excerpt 01.

Excerpt 01 (Participant \# 11)

I think in speaking, word pronunciation ... I mean the accurate pronunciation ... is very important. Your speech cannot be understood if you have inappropriate pronunciation. In this way, your listeners will miss what you intend to say. Like what we are doing now, do you understand what I am talking about now? You know the reason, of course. Because you understand my pronunciation; otherwise, you will be lost. I think, it's not necessary for me to speak fast or fluently if my pronunciation is bad or not accurate. So, pronunciation accuracy, in my opinion, is very important. It will determine whether you will be understood or not by listeners.

They claimed that the reasons for the importance of word pronunciation accuracy were partly because some English phonemes did not exist in their mother tongue (L1) or partly because of different distribution of the same sounds in English and their L1. Additionally, regarding the pronunciation of English words and their alphabet representation, English pronunciation becomes more complicated. This is because English is recognised as a deep language, meaning that you have the same spellings with different pronunciation and you have the same pronunciation with different spellings (Moedjito, 2017). For example, the spelling of $\langle\mathrm{c}\rangle$ as in 'cycle', the first $\langle\mathrm{c}\rangle$ is differently pronounced from the second $\langle\mathrm{c}\rangle$. The first $\langle\mathrm{c}\rangle$ is pronounced as /s/ and the second $\langle\mathrm{c}\rangle$ is pronounced as $/ \mathrm{k} /$. So, the correct pronunciation of the 'cycle' is /sarkl/. Another example is the $\langle\mathrm{ff}\rangle$ as in the word 'staff' and $<\mathrm{gh}>$ as in the word 'enough.' Although they are written in different spellings, their pronunciations are the same, namely /f/. So, the first word is pronounced as /sta:f/ and the second word is pronounced as $/ \mathrm{In} \Lambda \mathrm{f} /$. Thus, it is not easy for EFL speakers to learn English pronunciation. These conditions would get worse when they had neither pronunciation instruction nor pronunciation assessment in their classsrooms. What they actually needed was teachers' or instructors' explanation about how to produce accurate sounds-whether in their L1 or in English as the target language. Thus, they suggested that pronunciation instruction and evaluation should be a part of English teaching and learning in their classrooms. 
Unrelated to pronunciation but still related to the EFL speakers' oral performance, all the participants of the study claimed that vocabulary still dominated other aspects of speaking, such as grammatical structures and fluency. Most of the EFL participants believed that vocabulary came after word pronunciation accuracy to make their utterances more understandable by listeners. In fact, this belief does not directly correlate to intelligibility, rather to effective utterances. According to Catford (1967), utterances should be both intelligible and effective; otherwise, the message being sent cannot be properly percieved by listeners. Related to other factors influencing EFL speakers' intelligibility, one of the participants argued that vocabulary took at the second place as illustrated in Excerpt 02.

Excerpt 02 (Participant \#27)

... You see that a language is almost the same as our body. It consists of bones, flesh, and skin. Bones are just like grammatical structures; flesh is just like vocabulary, and skin is similar to pronunciation. So, which one do you think the most important? Bones? Flesh? Or skin? Just imagine if we don't have one of them. But among the three, you may choose the one which is the most crucial. In my opinion, skin is the most important because we can see how a person is just because of his/her appearance. And the next, it must be the flesh as it will shape your body. Finally, the last one should be the bones. Without bones, neither can we sit down nor stand up. So, coming back to a language, once again in my opinion, the most important is word pronunciation accuracy, sequentially followed by proper vocabulary and grammatical structures.

The main purpose of the present study was to investigate the factors which made EFL speakers' utterances more intelligible in the context of global intelligibility. After collecting and analysing data, the findings of the study have shown that word pronunciation accuracy is regarded as the priority for determining intelligibility, meaning that word pronunciation accuracy has more important role in predicting EFL speakers' intelligibility than other investigated variables. This is partly consistent with the findings of the previous studies which discovered the relative importance of segmental features to intelligibility (Becker \& Kluge, 2014; Jenkins, 2002; Moedjito, 2009; 2016b; Rajadurai, 2007; Saito, 2014). For example, Jenkins proposes Lingua Franca Core (LFC) as a crucial safeguard for intelligibility between non-native English speakers (Jenkins, 1998; 2000). On the basis of her empirical research, Jenkins suggests that LFC should cover all consonant sounds (except the pair of inter-dental fricatives $/ \theta /$ and $/ \delta /$, and the dark $/ 1 /$ or [1]), vowel sounds, and nuclear stresses. Similarly, the findings of the present study also support some previous studies conducted by Moedjito (2009; 2016b; in press) although we used different materials. In 2009 Moedjito used recorded one minute oral performance presented to the native and ESL speaker assessors when collecting data while in 2016 Moedjito distributed a questionnaire to the EFL participants. Meanwhile, in the present study the researchers used both of questionnaire and real life utterances collected from in-depth interview. In short, we can say that whatever instruments or materials we used in our research, the finding has mostly revealed that word pronunciation might be the most crucial for EFL speakers' intelligibility. A recent study which investigated nuclear stress as a candidate for a factor determining gobal intelligibility among EFL learners discovered that nuclear stress did not have an important role for global intelligibility because the EFL participants focused more on the accurate pronunciation which might contribute significantly to intelligibility (Moedjito, 2018).

Another insteresting finding of the present study is related to potential contributing factor to intelligibility which is not a part of pronunciation, namely lexical accuracy. One of the results of the data analyses has revealed that vocabulary might be the next important factor to EFL speakers' intellgibility. This implies that if an EFL speaker has a good pronunciation but he chooses inappropriate word, his utterance might not be well understood by listeners. This phonemenon is consonant with Catford's (1967) proposition which puts intelligibility and effectiveness in the relatively same position. To support his proposition, he provides an imaginary example of a foreign guest at an English teaparty where there are two kinds of baked sweetmeats, cakes and tarts. The guest wants to get a tart. Because of his limited vocabulary, he asks for a cake instead of a tart. The hostess passes him the plate of cakes. According to Catford (1967), this situation shows that the speaker's utterance is perfectly intelligible but ineffective. This is because the hostess' response is not appropriate to his purpose in speaking.

\section{CONCLUSION}

The present study aimed at examining the factors which made EFL speakers' utterances more intelligible in the context of global inetelligibility. The main finding of the study is that both of word pronunciation accuracy and lexical accuracy should be considered as the common primary factors contributing global intelligibility. The data analyses have discovered that word pronunciation accuracy becomes the first prominent factor for EFL speakers' global intelligibility while vocabulary, which is not related to pronunciation, comes as the second crucial factor. Lack of one of them means less intelligible or misintepreted, even unintelligible. Thus, assuming that global intelligibility-the property which NNSs need to communicate to NSs and to other NNSs - should be the aim of pronunciation teaching in the context of English as a global language, word pronunciation accuracy should be revisited as one of the crucial elements in pronunciation teaching, in terms of which segmental features of English pronunciation should be the priorities and which techniques are approriate in pronunciation teaching in EFL classrooms.

Although our study has revealed several interesting facts about factors determining intelligibility of EFL 
speakers' oral communication, we must admit that the study has also several limitations. First, the data analysis was based on EFL speakers' utterances on topics related to the participants' experience in learning English in general and their opinion on English pronunciation and learning English pronunciation which they might not be interested in or they had lack of knowledge of pronunciation. In the next research, the topic of investigation should be directed to the one which is more familiar with them so that we can elicit much more information. Secondly, the participants of the study were limited to European EFL speakers as the providers of the EFL speakers' utterances. In the future, the participants can be extended to Asian or African who have more a variety of first linguistic backgrounds. Thirdly, the fixed sequence of the investigated components used in the assessment sheet may have had some unpredictable influence on the assessors' evaluation of the EFL speakers' utterances. We should also improve the rubrics used for the assessment so that assessors can evaluate EFL learners' utterances with more confidence and efficiency. Different sequences of the investigated factors determining global intelligibility should also be used in our replication so that we can minimise unpredictable effects caused by the fixed order of the components.

We acknowledge that the instrument used in the present study has much to be improved but we believe that the findings of the study will serve as the point of reference for English pronunciation teaching, including developing appropriate teaching materials and assessing EFL learners' global intelligibility.

The major pedagogical implication is that in any English pronunciation teaching there should be more focus on word pronunciation accuracy. We should not neglect the importance of these segmental features, which have been slid in the current practice of communicative language teaching in favour of discourse features. The motto more focus on what to say than how to say should be replaced by the case for good balance of what to say and how to say.

\section{ACKNOWLEDGEMENTS}

The present study was financially supported by the Directorate of Research and Community Service, Ministry of Research, Technology, Higher Education of the Republic of Indonesia (Grant Number: 0045/E3/LL/2018). I would also thank to seven Indonesian students who helped during data collection.

\section{REFERENCES}

Abercrombie, D. (1956). Problems and principles in language study (2nd ed.). London: Longmans, Green and Co. Ltd.

Baese-Berk, M. M. (2017). Factors influencing intelligibility and fluency in non-native speech. The Journal of the Acoustical Society of America 141(5), 3515. doi: 10.1121/1.4987381
Becker, M. R., \& Kluge, D. C. (2014). Intelligibility of English as a lingua franca (ELF): Perception by speakers of Brazilian Portuguese. Proceedings of the International Symposium on the Acquisition of Second Language Speech: Concordia Working Papers in Applied Linguistics, 5.

Campanella, E., \& Dassù, M. (February 21, 2017). A future of the English-speaking peoples: Lie back and think of the Anglosphere. Snapshot.

Catford, J. C. (1967). Intelligibility. In W. R. Lee (Ed.). ELT Selection 2 (pp. 142-150). Oxford: Oxford University Press.

Celce-Murcia, M., Brinton, D. M., \& Goodwin, J. M. (1996). Teaching pronunciation: A reference for teachers of English to speakers of other languages. Cambridge: Cambridge University Press.

Cole, S. (2002). An investigation of the role of vowel quality for intelligibility in oral interactions between NNSs of English as an international language. Speak Out! 29.

Cruttenden, A. (2001). Gimson's pronunciation of English (6th ed.). London: Arnold Publisher.

Gilakjani, A. P., \& Ahmadi, M. R. (2011). Why is pronunciation so difficult to learn? English Language Teaching 4(3), 74-83. doi: 10.5539/elt.v4n3p74

Graddol, D. (1997). The future of English? London: The British Council.

Graddol, D. (2006). English next. London: The British Council.

Internet World Stats. (2018). Internet world users by language: Top 10 Languages. Retrieved from: https://internetworldstats. com/stats7.htm

Jenkins, J. (1998). Which pronunciation norms and models for English as an international language? ELT Journal, 5(2), 119-126. doi: 10.1093/elt/52.2.119

Jenkins, J. (2000). The phonology of English as an international language. Oxford: Oxford University Press.

Jenkins, J. (2002). A sociolinguistically based, empirical researched pronunciation syllabus for English as an international language. Applied Linguistics 23(1), p. 83-103. doi: 10.1093/applin/23.1.83

Karoń, J. (2012). Factors influencing intelligibility and the occurrence of communication breakdowns in spoken utterances: The analysis of the pilot study conducted in a group of Polish users of English. The EDULEARN12 Proceedings of the 4th International Conference on Education and New Learning Technologies. Barcelona, Spain.

Kurum, E. Y. (2016). Teaching Speaking Skills. In Solak, E. (Ed.). Teaching Language Skills for Prospective English Teachers (pp. 45-64). Publisher: Pelikan.

Lyons, D. (16 July 2017). How Many People Speak English, And Where Is It Spoken? Babbel Magazine. https://www.babbel.com/ en/magazine/how-many-people-speak-english-andwhere-is-it-spoken 
McArthur, T. (1992). Oxford Companion to the English Language. Oxford, UK: Oxford University Press.

McHugh, M. L. (2012). Interrater reliability: the Kappa statistic. Biochem Med (Zagreb) 22(3), 276-82.

Moedjito. (2009). A study on factors determining global intelligibility of EFL learners' speech (Unpublished Doctoral Thesis, Hyogo University of Teacher Education, Japan).

Moedjito. (2016a). Basic statistics for research in language education. Surakarta: PT Yuma Pustaka.

Moedjito. (2016b). The teaching of English Pronunciation: Perceptions of Indonesian school teachers and university students. English Language Teaching 9(6), 1-12. doi: 10.5539/elt.v9n6p30

Moedjito. (2017). Engish Pronunciation Practice. Lombok Timur: Universitas Hamzanwadi Press.

Moedjito. (2018). Nuclear stress in oral communication among EFL speakers: Is it important or not? VELES Voices of English Language Education Society 2(2), 127-40. doi: 10.30870/jels.v3i1.2582

Morley, J. (1991). The pronunciation component in teaching English to speakers of other languages. TESOL Quarterly 25(3), 481-521. doi: $10.2307 / 3586981$

Munro, M. J. (2011). Intelligibility: Buzzword or buzzworthy? In. J. Levis \& K. LeVelle (Eds.).
Proceedings of the 2nd Pronunciation in Second Language Learning and Teaching Conference (pp. 7-16). Ames, IA: Iowa State University.

Rajadurai, J. (2007). Intelligible pronunciation: Focus on the proficient L2 speakers. The Journal of Asia TEFL 4(1), 1-25.

Saito, K. (2014). Experienced teachers' perspectives on priorities for improved intelligible pronunciation: The case of Japanese learners of English. International Journal of Applied Linguistics 24(2), 250-277.

The Statistics Portal. (2018). Number of international tourist arrivals worldwide 2005-2017 by region. https://www.statista.com/statistics/186743/internat ional-tourist-arrivals-worldwide-by-region-since2005/

von Schon, C. V. (1987). The question of pronunciation. English Teaching Forum 25(4), 22-27.

Walker, R. (2001). Pronunciation for international intelligibility. English Teaching Professional 21. Available at https://englishglobalcom.files.wordpress.com/2013 /12/pronunciation-for-internationalintelligibility2.pdf

Zielinski, B. (2006). The intelligibility cocktail: An interaction between speaker and listener ingredients. Prospect, 21(1), 22-45. 


\section{APPENDIX}

Assessment Sheet

Instruction: Please evaluate the EFL utterances by circling the number representing the characteristics.

\begin{tabular}{|c|c|c|c|c|c|}
\hline \multirow{3}{*}{$\begin{array}{l}\text { Grammatical } \\
\text { Accuracy }\end{array}$} & \multicolumn{5}{|c|}{ Grammatical accuracy refers to the ability to use grammatical structures properly. } \\
\hline & 1 & 2 & 3 & 4 & 5 \\
\hline & $\begin{array}{l}\text { A great number of } \\
\text { grammatical errors are } \\
\text { present. }\end{array}$ & $\begin{array}{l}\text { Many grammatical } \\
\text { errors are present. }\end{array}$ & $\begin{array}{l}\text { Some grammatical } \\
\text { errors are present. }\end{array}$ & $\begin{array}{l}\text { Few grammatical } \\
\text { errors are present. }\end{array}$ & $\begin{array}{l}\text { Almost no } \\
\text { grammatical errors are } \\
\text { present. }\end{array}$ \\
\hline \multirow{3}{*}{$\begin{array}{l}\text { Lexical } \\
\text { Accuracy }\end{array}$} & \multicolumn{5}{|c|}{ Lexical accuracy refers to the ability to use vocabulary properly. } \\
\hline & 1 & 2 & 3 & 4 & 5 \\
\hline & $\begin{array}{l}\text { A great number of } \\
\text { lexical errors are } \\
\text { present. }\end{array}$ & $\begin{array}{l}\text { Many lexical errors } \\
\text { are present. }\end{array}$ & $\begin{array}{l}\text { Some lexical errors are } \\
\text { present. }\end{array}$ & $\begin{array}{l}\text { Few lexical errors are } \\
\text { present. }\end{array}$ & $\begin{array}{l}\text { Almost no lexical } \\
\text { errors are present. }\end{array}$ \\
\hline \multirow{3}{*}{$\begin{array}{l}\text { Word } \\
\text { Pronunciation } \\
\text { Acuracy }\end{array}$} & \multicolumn{5}{|c|}{ Word pronunciation accuracy refers to the ability to produce individual sounds (consonants and vowels) properly. } \\
\hline & 1 & 2 & 3 & 4 & 5 \\
\hline & $\begin{array}{l}\text { A great number of } \\
\text { mispronunciations are } \\
\text { present. }\end{array}$ & $\begin{array}{l}\text { Many } \\
\text { mispronunciations are } \\
\text { present. }\end{array}$ & $\begin{array}{l}\text { Some } \\
\text { mispronunciations are } \\
\text { present. }\end{array}$ & $\begin{array}{l}\text { Few } \\
\text { mispronunciations are } \\
\text { present. }\end{array}$ & $\begin{array}{l}\text { Almost no } \\
\text { mispronunciations are } \\
\text { present. }\end{array}$ \\
\hline \multirow[t]{3}{*}{ Word Stress } & \multicolumn{5}{|c|}{ Stress refers to the combination of stressed and unstressed syllables in words. } \\
\hline & 1 & 2 & 3 & 4 & 5 \\
\hline & $\begin{array}{l}\text { A great number of } \\
\text { incorrect placements of } \\
\text { word stress are present. }\end{array}$ & $\begin{array}{l}\text { Many incorrect } \\
\text { placements of word } \\
\text { stress are present. }\end{array}$ & $\begin{array}{l}\text { Some incorrect } \\
\text { placements of word } \\
\text { stress are present. }\end{array}$ & $\begin{array}{l}\text { Few incorrect } \\
\text { placements of word } \\
\text { stress are present. }\end{array}$ & $\begin{array}{l}\text { Almost no incorrect } \\
\text { placements of word } \\
\text { stress are present. }\end{array}$ \\
\hline \multirow[t]{3}{*}{ Nuclear Stress } & \multicolumn{5}{|c|}{$\begin{array}{l}\text { Nuclear stress refers to which word in a sentence the speaker wishes to highlight on the basis of either old-new information, } \\
\text { special emphasis on a particular element, or contrastive elements. }\end{array}$} \\
\hline & 1 & 2 & 3 & 4 & 5 \\
\hline & $\begin{array}{l}\text { Almost no correct } \\
\text { placements of correct } \\
\text { sentence stress are } \\
\text { present. }\end{array}$ & $\begin{array}{l}\text { Few correct } \\
\text { placements of correct } \\
\text { sentence stress are } \\
\text { present. }\end{array}$ & $\begin{array}{l}\text { Some correct } \\
\text { placements of correct } \\
\text { sentence stress are } \\
\text { present. }\end{array}$ & $\begin{array}{l}\text { Many correct } \\
\text { placements of correct } \\
\text { sentence stress are } \\
\text { present. }\end{array}$ & $\begin{array}{l}\text { Almost all correct } \\
\text { placements of correct } \\
\text { sentence stress are } \\
\text { present. }\end{array}$ \\
\hline \multirow{3}{*}{$\begin{array}{l}\text { Adjustments in } \\
\text { Connected } \\
\text { Speech }\end{array}$} & \multicolumn{5}{|c|}{$\begin{array}{l}\text { Adjustments in connected speech refer to the process of blending words within a single thought group, including the consonant- } \\
\text { to-vowel linking, vowel-to-vowel linking, consonant assimilation, and palatalization. }\end{array}$} \\
\hline & 1 & 2 & 3 & 4 & 5 \\
\hline & $\begin{array}{l}\text { Almost no adjustments } \\
\text { in connected speech } \\
\text { occur. }\end{array}$ & $\begin{array}{l}\text { Few adjustments in } \\
\text { connected speech } \\
\text { occur. }\end{array}$ & $\begin{array}{l}\text { Some adjustments in } \\
\text { connected speech } \\
\text { occur. }\end{array}$ & $\begin{array}{l}\text { Many adjustments in } \\
\text { connected speech } \\
\text { occur. }\end{array}$ & $\begin{array}{l}\text { Almost all adjustments } \\
\text { in connected speech } \\
\text { occur. }\end{array}$ \\
\hline \multirow[t]{3}{*}{ Intonation } & \multicolumn{5}{|c|}{ Intonation refers to the way the reader varies the voice in tone, pitch, and volume to reflect the meaning of the speech. } \\
\hline & 1 & 2 & 3 & 4 & 5 \\
\hline & $\begin{array}{l}\text { Extremely disturbing; } \\
\text { great additional } \\
\text { listener effort is } \\
\text { required. }\end{array}$ & $\begin{array}{l}\text { Disturbing; much } \\
\text { additional listener } \\
\text { effort is required. }\end{array}$ & $\begin{array}{l}\text { Somewhat disturbing; } \\
\text { some additional } \\
\text { listener effort is } \\
\text { required. }\end{array}$ & $\begin{array}{l}\text { Little disturbing; little } \\
\text { additional listener } \\
\text { effort is required. }\end{array}$ & $\begin{array}{l}\text { Not disturbing at all; } \\
\text { no additional listener } \\
\text { effort is required. }\end{array}$ \\
\hline \multirow[t]{3}{*}{ Rhythm } & \multicolumn{5}{|c|}{ Rhythm refers to the regular, patterned beat of stressed and unstressed syllables and pauses. } \\
\hline & 1 & 2 & 3 & 4 & 5 \\
\hline & $\begin{array}{l}\text { Extremely disturbing; } \\
\text { great additional } \\
\text { listener effort is } \\
\text { required. }\end{array}$ & $\begin{array}{l}\text { Disturbing; much } \\
\text { additional listener } \\
\text { effort is required. }\end{array}$ & $\begin{array}{l}\text { Somewhat disturbing; } \\
\text { some additional } \\
\text { listener effort is } \\
\text { required. }\end{array}$ & $\begin{array}{l}\text { Little disturbing; little } \\
\text { additional listener } \\
\text { effort is required. }\end{array}$ & $\begin{array}{l}\text { Not disturbing at all; } \\
\text { no additional listener } \\
\text { effort is required. }\end{array}$ \\
\hline \multirow[t]{3}{*}{ Fluency } & \multicolumn{5}{|c|}{ Fluency refers to the property of a person that delivers information smoothly and effortlessly. } \\
\hline & 1 & 2 & 3 & 4 & 5 \\
\hline & $\begin{array}{l}\text { A great number of } \\
\text { pauses and corrections } \\
\text { occur. }\end{array}$ & $\begin{array}{l}\text { Many pauses and } \\
\text { corrections occur. }\end{array}$ & $\begin{array}{l}\text { Some pauses and } \\
\text { corrections occur. }\end{array}$ & $\begin{array}{l}\text { Few pauses and } \\
\text { corrections occur. }\end{array}$ & $\begin{array}{l}\text { Almost no pauses and } \\
\text { corrections occur. }\end{array}$ \\
\hline \multirow[t]{3}{*}{ Intelligibility } & \multicolumn{5}{|c|}{ Intelligibility refers to the property of a speaker which can be understood with little or no conscious effort on the part of listener. } \\
\hline & 1 & 2 & 3 & 4 & 5 \\
\hline & $\begin{array}{l}\text { Not intelligible at all; } \\
\text { great listener effort is } \\
\text { required. }\end{array}$ & $\begin{array}{l}\text { Little intelligible; } \\
\text { much listener effort is } \\
\text { required. }\end{array}$ & $\begin{array}{l}\text { Reasonably } \\
\text { intelligible; some } \\
\text { listener effort is } \\
\text { required. }\end{array}$ & $\begin{array}{l}\text { Largely intelligible; } \\
\text { little listener effort is } \\
\text { required. }\end{array}$ & $\begin{array}{l}\text { Fully intelligible; no } \\
\text { listener effort is } \\
\text { required. }\end{array}$ \\
\hline
\end{tabular}

\footnotetext{
Please write your comments on the EFL utterances, if any.
} 